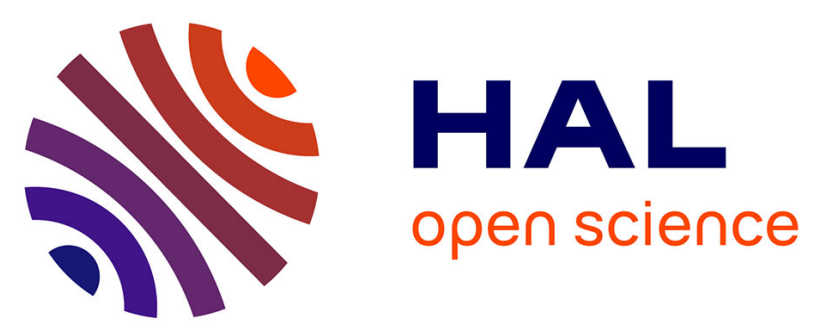

\title{
Copy-neutral loss of heterozygosity and chromosome gains and losses are frequent in gastrointestinal stromal tumors.
}

Nelson Lourenço, Zofia Hélias-Rodzewicz, Jean-Baptiste Bachet, Sabrina Brahimi-Adouane, Fabrice Jardin, Jeanne Tran van Nhieu, Frédérique Peschaud, Emmanuel Martin, Alain Beauchet, Frédéric Chibon, et al.

\section{To cite this version:}

Nelson Lourenço, Zofia Hélias-Rodzewicz, Jean-Baptiste Bachet, Sabrina Brahimi-Adouane, Fabrice Jardin, et al.. Copy-neutral loss of heterozygosity and chromosome gains and losses are frequent in gastrointestinal stromal tumors.. Molecular Cancer, 2014, 13 (1), pp.246. 10.1111/j.13652141.2009.07791.x . inserm-01188061

\section{HAL Id: inserm-01188061 https://www.hal.inserm.fr/inserm-01188061}

Submitted on 28 Aug 2015

HAL is a multi-disciplinary open access archive for the deposit and dissemination of scientific research documents, whether they are published or not. The documents may come from teaching and research institutions in France or abroad, or from public or private research centers.
L'archive ouverte pluridisciplinaire HAL, est destinée au dépôt et à la diffusion de documents scientifiques de niveau recherche, publiés ou non, émanant des établissements d'enseignement et de recherche français ou étrangers, des laboratoires publics ou privés. 


\title{
Copy-neutral loss of heterozygosity and chromosome gains and losses are frequent in gastrointestinal stromal tumors
}

\author{
Nelson Lourenço ${ }^{1,10 \dagger}$, Zofia Hélias-Rodzewicz ${ }^{1,2 \dagger}$, Jean-Baptiste Bachet ${ }^{1,3}$, Sabrina Brahimi-Adouane \\ Fabrice Jardin ${ }^{4}$, Jeanne Tran van Nhieu ${ }^{5}$, Frédérique Peschaud ${ }^{1,6}$, Emmanuel Martin $^{7}$, Alain Beauchet ${ }^{1,8}$, \\ Frédéric Chibon ${ }^{9}$ and Jean-François Emile ${ }^{1,2^{*}}$
}

\begin{abstract}
Background: A KIT gain of function mutation is present in $70 \%$ of gastrointestinal stromal tumors (GISTs) and the wild-type (WT) allele is deleted in 5 to $15 \%$ of these cases. The WT KIT is probably deleted during GIST progression. We aimed to identify the mechanism of WT KIT loss and to determine whether other genes are involved or affected.

Methods: Whole-genome SNP array analyses were performed in 22 GISTs with KIT exon 11 mutations, including 11 with WT loss, to investigate the mechanisms of WT allele deletion. CGH arrays and FISH were performed in some cases. Common genetic events were identified by SNP data analysis. The 9p21.3 locus was studied by multiplex quantification of genomic DNA.

Results: Chromosome instability involving the whole chromosome/chromosome arm (whole C/CA) was detected in 21/22 cases. The GISTs segregated in two groups based on their chromosome number: polyGISTs had numerous whole C/CA gains (mean 23, range [9 to 43]/3.11 [1 to 5]), whereas biGISTs had fewer aberrations. Whole C/CA losses were also frequent and found in both groups. There were numerous copy-neutral losses of heterozygosity (cnLOH) of whole C/CA in both polyGIST (7/9) and biGIST (9/13) groups. CnLOH were frequent on 4q, 11p, 11q, 1p, 2q, 3p and 10, and never involved 12p, 12q, 20p, 20q or 19q. Other genetic alterations included segmental chromosome abnormalities, complete bi-allelic deletions (homozygous deletions) and, more rarely, amplifications. Nine of 11 GISTs with homozygous KIT exon 11 mutations had cnLOH of chromosome 4.
\end{abstract}

Conclusion: The $\mathrm{CnLOH}$ of whole C/CA is a frequent genetic alteration in GISTs and is closely associated with homozygous mutations of KIT and WT allele deletion.

Keywords: $\mathrm{cnLOH}$, WT KIT allele loss, GIST

\section{Background}

About 20 to $30 \%$ of extra-osseous sarcomas are gastrointestinal stromal tumors [1] which are the most frequent mesenchymal tumors of the digestive tract. Before 1998, their diagnosis was difficult and they were frequently mistaken for muscular or nervous tumors. KIT [2] and PDGFRA [3] are main driver genes of GISTs. Indeed, gain of function mutations of these genes are

\footnotetext{
* Correspondence: jean-francois.emile@uvsq.fr

${ }^{\dagger}$ Equal contributors

'EA4340, Versailles University, Boulogne-Billancourt, France

${ }^{2}$ Department of Pathology, Ambroise Paré Hospital, APHP, 9 Avenue

Charles de Gaulle, Boulogne-Billancourt, France

Full list of author information is available at the end of the article
}

present in $85 \%$ of GISTs $[4,5]$ and KIT inhibitors increase survival of patients with metastatic or localized GISTs [6,7]. The KIT inhibitor imatinib mesylate is more effective in patients with mutations in exon 11 of $K I T$ than in those with KIT exon 9 mutations [8]. The KIT gene maps on chromosome 4q12 and encodes the protein KIT, a tyrosine kinase receptor, the activation of which leads to cell proliferation, differentiation, migration or increased survival [9]. KIT mutations are early events in GIST oncogenesis [10], and patients with germinal mutation of KIT have a high incidence of GISTs [11]. Cytogenetic studies of GISTs with karyotyping, 
fluorescence in situ hybridization (FISH) and/or comparative genomic hybridization $(\mathrm{CGH})$ arrays have shown that many of these tumors have gains or losses in chromosomes 5 and/or 8 , and losses in 1p, 14q, 15q and 22q [12-21].

The most frequent mutations of KIT map in exon 11. In most GISTs, both mutated and wild-type transcripts are present [22]. However, 5 to $15 \%$ of GISTs have loss of the KIT WT allele from genomic tumor DNA [23]. Expression of mutant KIT in the presence of WT KIT in vitro has particular cellular effects, different to those associated with the expression of the mutant alone [24,25]. Patients with loss of WT KIT have a worse prognosis than those with GISTs containing both WT and mutant alleles of $K I T[23,26]$.

We used high density whole-genome single-nucleotide polymorphism (SNP) arrays to study the mechanism of the WT allele loss in GISTs with KIT exon 11 mutations and analyze chromosome abnormalities in GISTs.

\section{Results}

Polyploidy validation by FISH

Chromosome number aberrations revealed by at least one bioinformatics method (from SNP and CGH array data) and detailed visual analysis of SNP genetic data (both copy number alterations (CNA) and allele disequilibrium (AD)) in BeadStudio software were concordant for 19 tumors. In three cases (\#1C2, \#15C2 and \#20 s2), the results of bioinformatics analysis suggested diploid tumors; however, the visual investigation of CNA and $\mathrm{AD}$ data indicated ploidy higher than two (Figure 1A). The different ploidy levels were verified by FISH on the imprints of GIST cell nuclei with at least two different chromosome probes and confirmed the results of detailed visual analysis of SNP genomic data (Figure 1B). For cases \#1C2 and \#20 s2, chromosomes 4q, 7q, 17q, 18 and $22 \mathrm{q}$ were tested. Most \#20 s2 cells analyzed were polysomic for chromosomes $4 \mathrm{q}$ (mean chromosome number
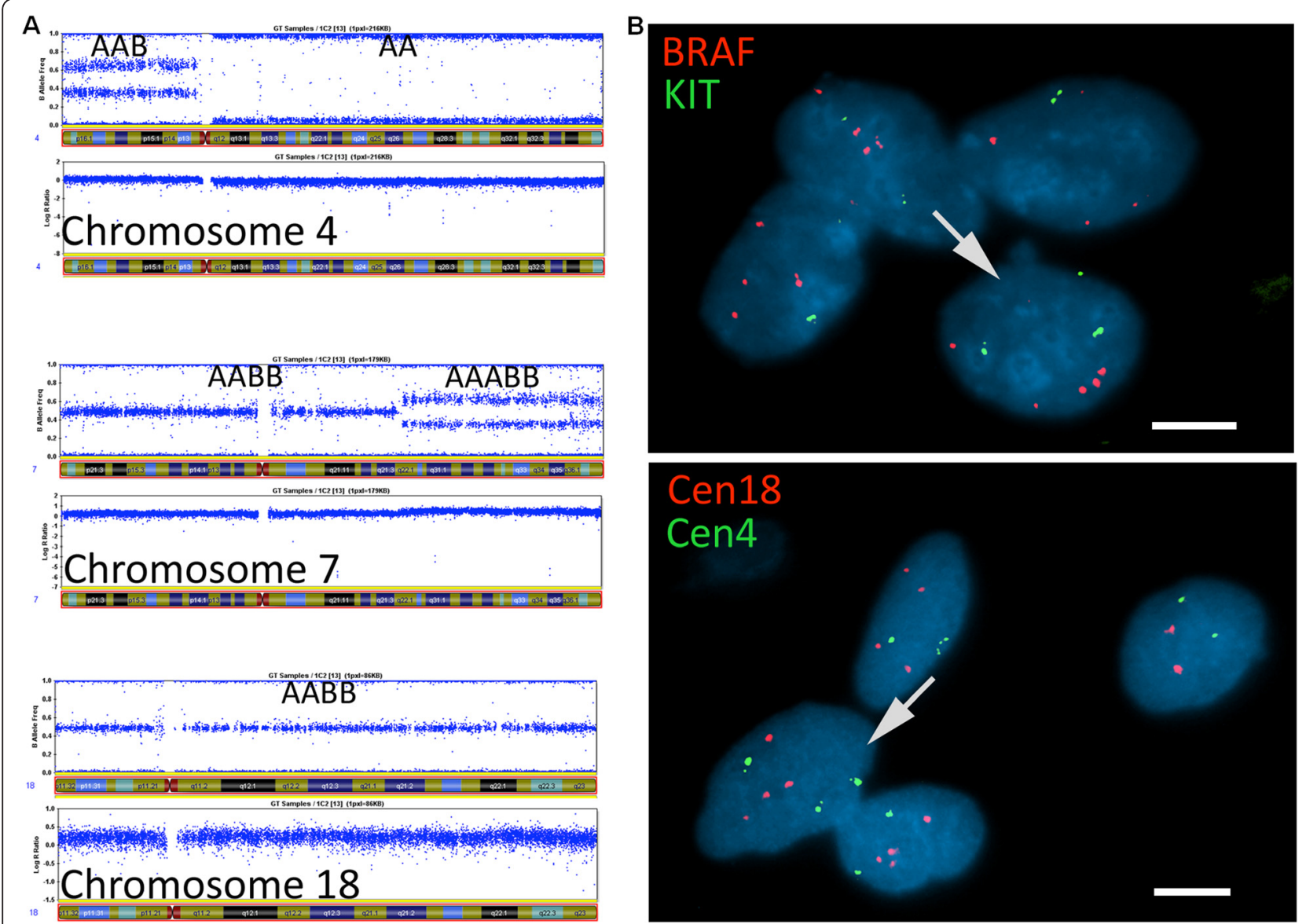

Figure 1 Example of ploidy analysis by FISH with one GIST (\#1C2). A) (Left) for chromosomes 4, 7 and 18, allele frequencies (upper plot) and copy number alteration (bottom plot) are presented. The results of visual genotyping of both parental alleles are indicated as " $\mathbf{A}$ " and "B" within the upper plot for each chromosome. B) (Right) representative images of FISH analysis of the same tumor for the same chromosomes. On the upper image, the arrow indicates a cell with two chromosomes $4 q$ and five chromosomes $7 q$. On the lower image, the arrow indicates a cell with four chromosomes 18 and three chromosome 4 centromeric signals. White bar $=10 \mu \mathrm{m}$. 
3.2, range [2 to 4]), 7q (mean 3.2, range [1 to 4]), 17q (mean 3.2 , range [1 to 4 ]) and 18 (mean 3.1, range [2 to 4]) (the expected chromosome number was four copies for all these chromosomes). All cells analyzed for chromosome 22q had two copies; however, SNP data suggested only one copy of this chromosome. In \#1C2 samples, most nuclei analyzed for chromosomes 7q, 17q and 18 were polysomic: the mean chromosomes number/expected chromosome number was 4.4, range [3 to 8]/6 (BRAF 7q34), 3.4, range [1 to 6]/3 and 3.6 , range [2 to 4$] / 4$, respectively. In most cells, two copies of chromosomes 4q (mean chromosome number 2.2, range [1 to 3 ]) and $22 \mathrm{q}$ (mean 2.4 , range [1 to 4 ]) were observed as expected from the SNP analysis. For tumor sample \#15C2, FISH signals were only interpretable for chromosomes $17 \mathrm{q}$ and $22 \mathrm{q}$. Most of the nuclei displayed polysomy of chromosome $22 \mathrm{q}$ (mean 2.5 , range [1 to 4]) but almost all cells were only diploid for chromosome 17q (mean 2, range [1 to 3]); four copies of both chromosomes were expected.

\section{Chromosome alterations}

Numerous chromosome aberrations were observed, and most were either quantitative or qualitative. Whole genomic views of the chromosome copy number alterations and allele disequilibrium are shown in Figure 2. Quantitative abnormalities included either gains (1 copy or more) or losses (1 copy or more) of whole chromosomes (C), chromosome arms (CA) and/or chromosome segments (CS) (Figure 2, Table 1, Additional file 1: Figure S1, Additional file 2: Table S1). GISTs were classified into two groups according to chromosome number: polyploid GISTs called polyGISTs with numerous gains and few losses of whole $C(n=9$, mean whole $C$ gains 23 , range [9 to 43 ] and mean whole $C$ losses 0.44 , range [0 to 3 ]) and diploid tumors called biGISTs with few gains of whole $C$ and few losses of whole C or CA $(n=13$, mean whole $C$ gains 0.07 , range [0 to 1$]$, mean whole $\mathrm{C}$ losses 2.33, range [0 to 6] and mean CA losses 1.46, range [0 to 5]) (Figure 2). Tumors were classified as polyploid if at least five different whole chromosomes were gained. The biGIST group contained tumors with near diploid chromosomes sets.

Gains of whole C and CA were detected in 10/22 (45\%) and 16/22 GISTs (73\%), respectively. In biGISTs, the mean gains were 0.07 (range [0 to 1]) and 0.85 (range [0 to 4]) for whole $\mathrm{C}$ and $\mathrm{CA}$, respectively, while in polyGISTs the mean gains were 23 (range [9 to 43]) and 3.11 (range [1 to 5]) for whole $\mathrm{C}$ and $\mathrm{CA}$, respectively. Among the 13 biGISTs, only one (8\%) had a whole $C$ gain and 7 (54\%) had an increased CA number (Figure 2, Table 1, Additional file 2: Table S1). By contrast, all polyGISTs had gained additional whole $\mathrm{C}$ or CA. Every type of gain was present in at least two patients. The most frequently gained $\mathrm{C}$ and CA (observed in at least 35\% of
GISTs) were: 1q, 2, 4p, 5, 5p, 7, 8, 12, 16, 17q, 18, 19p and 20. In additional to whole C/CA gains, CS gains were detected in all polyGISTs but in only $4 / 13$ biGISTs (31\%) (Figure 2, Table 1, Additional file 2: Table S1) (biGISTs mean CS gains 0.77 , range [0 to 4 ]; polyGISTs mean CS gains 10 , range [0 to 35$], \mathrm{P}<0.05)$. Most of the segmental copy number abnormalities were found in chromosomes involved in whole chromosome or chromosomal arm imbalances, and $31 \%$ of them were telomeric.

Losses, defined as the presence of only one copy of a whole C or a CA, were detected in 14/22 (63\%) and 10/22 (45\%) of GISTs, respectively (Figure 2, Table 1, Additional file 2: Table S1). They were more frequent in biGISTs than in polyGISTs (biGISTs mean whole C losses 2.23 , range [0 to 6] and mean CA losses 1.46, range [0 to 5]; polyGISTs mean whole $C$ losses 0.44 , range [0 to 3 ] and mean $C A$ losses 0 [0], $\mathrm{P}<0.05)$. The $\mathrm{C}$ and $\mathrm{CA}$ most frequently involved (deleted in more than $20 \%$ of GISTs) were: 14 $(n=50 \%), 22(n=41 \%), 1 p(n=36 \%)$ and $15(n=27 \%)$. Segmental copy number losses were mainly found in the chromosomes involved in whole $\mathrm{C}$ or CA abnormalities: they were frequent in biGISTs $(9 / 13)$, but rare in polyGISTs (2/9), and $38 \%$ of them were telomeric (biGISTs mean CS losses 3.23, range [0 to 9]; polyGISTs mean CS losses 1.33, range [0 to 10]); however the difference was not significant $(P=0.2)$.

\section{Copy neutral loss of heterozygosity}

Copy-neutral loss of heterozygosity $(\mathrm{cnLOH})$ was frequent in our samples. Three types of $\mathrm{cnLOH}$ were observed involving whole chromosomes, chromosome arms and/or chromosome segments. Whole $\mathrm{C}$ and $\mathrm{CA}$ cnLOH were detected in $16 / 22(73 \%)$ tumors (7/9 polyGISTs and 9/13 biGISTs) (Figure 2, Table 1, Additional file 2: Table S1). The most frequently involved arms were: $4 \mathrm{q}(41 \%), 11 \mathrm{p}$ (27\%), 11q (23\%), 1p (18\%), 2q (18\%), 3p (18\%) and 10 (18\%). Chromosome arms 12p, 12q, 19p, 20p and 20q were never involved in $\mathrm{cnLOH}$. Gains with $\mathrm{LOH}$ were detected in three polyGISTs and were associated with three and four copies of a small number of chromosomes.

\section{Identification of commonly altered regions}

All genotyping data (copy number alterations and allele disequilibrium) were examined and combined to identify the most frequently altered common overlapping regions. Sixty-nine common overlapping regions were identified (Additional file 3: Table S2): each was altered in more than $20 \%$ of tumors. They were between $70 \mathrm{~kb}$ and $6100 \mathrm{~kb}$ long, and included one to 48 genes.

\section{Homozygous deletion and amplification}

Numerous bi-allelic deletions (homozygous deletions) were detected. However, most of these bi-allelic deletions were considered to not be significant: they were 


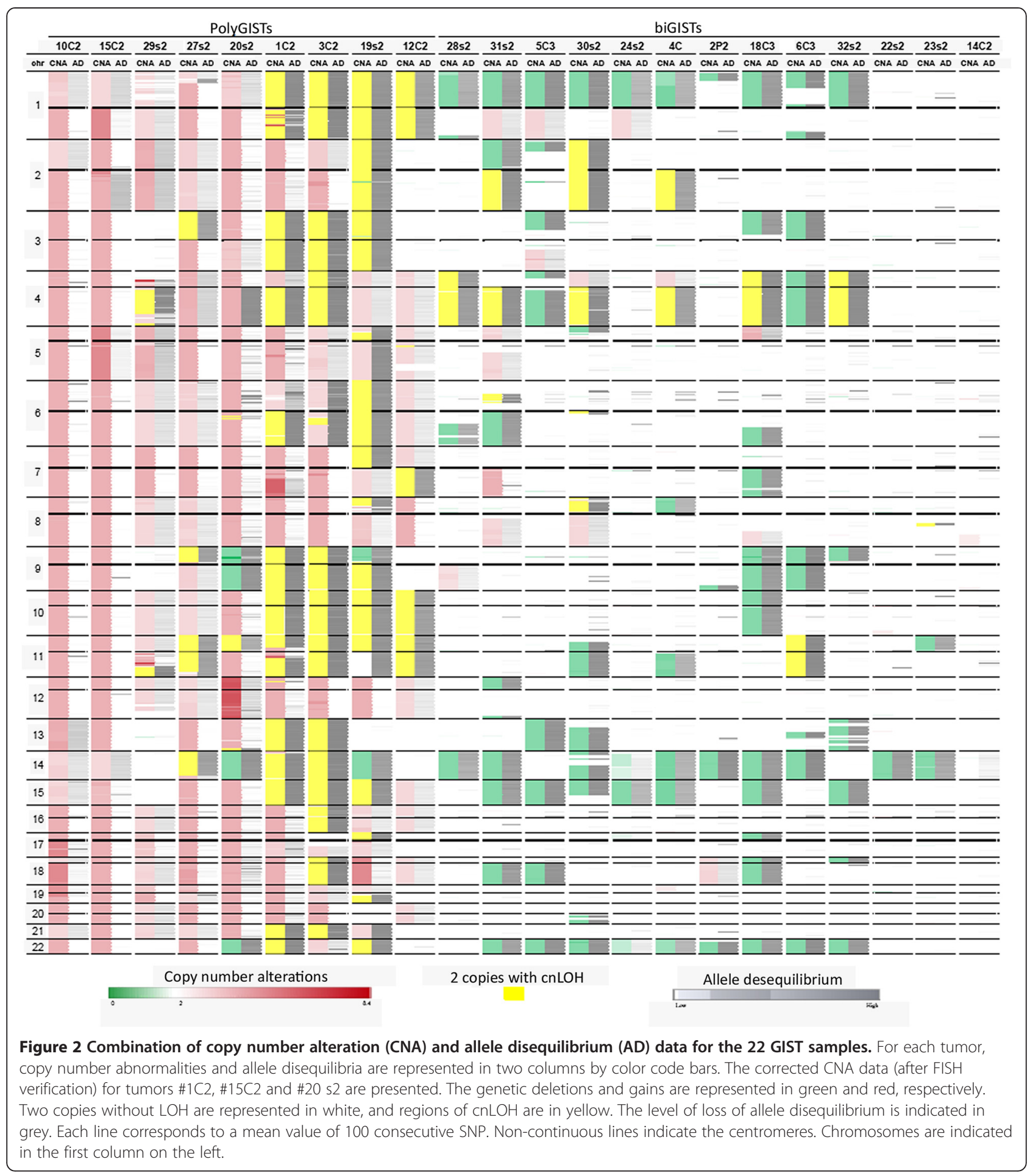

smaller than $100 \mathrm{~kb}$ or included fewer than 30 SNP. Larger bi-allelic deletions of 48 regions were detected in 16 tumors and involved numerous different genes (Table 2). Most of these bi-allelic deletions were detected only once, but some were observed in at least two cases. For example, $C D K N 2 A$ and $C D K N 2 B$ in 9p21.3 were deleted in four different GISTs. The known cellular functions of
13 deleted genes implicate them in oncogenesis (Table 2). Three genes with bi-allelic deletion (CDKN2A, CDKN2B, TUSC1) map in two of the most frequently altered common overlapping regions. One region on chromosome 8 was deleted in five GISTs and one on chromosome 11 in two GISTs. They encompassed the same SNPs in all corresponding samples, possibly suggesting polymorphism 
Table 1 Summary of mean chromosome number abnormalities in tumors and the \% of GISTs harboring the corresponding type of chromosome aberrations

\begin{tabular}{|c|c|c|c|c|c|c|c|}
\hline GIST groups & $\begin{array}{c}\text { Type of chromosome } \\
\text { aberration }\end{array}$ & $\begin{array}{c}\text { Average nb of } \\
\text { losses/tumor } \\
\text { [min-max] }\end{array}$ & $\%$ of GIST & $\begin{array}{c}\text { Average nb of } \\
\text { gains/tumor } \\
\text { [min-max] }\end{array}$ & $\%$ of GIST & $\begin{array}{c}\text { Average nb of } \\
\text { cnLOH/tumor } \\
\text { [min-max] }\end{array}$ & $\%$ of GIST \\
\hline \multirow[t]{3}{*}{ PolyGIST $(n=9)$} & Whole chr. & $0.44[0-3]$ & $22 \%$ & $23[9-43]$ & $100 \%$ & $3.67[0-12]$ & $55 \%$ \\
\hline & Chr. Arm & $0[0]$ & $0 \%$ & $3.11[1-5]$ & $100 \%$ & $1.11[0-3]$ & $55 \%$ \\
\hline & Segmental & $1.33[0-10]$ & $22 \%$ & 10 [0-35] & $100 \%$ & $2.67[0-7]$ & $44 \%$ \\
\hline \multirow[t]{3}{*}{ BiGIST $(n=13)$} & Whole chr. & $2.23[0-6]$ & $92 \%$ & $0.07[0-1]$ & $8 \%$ & $0.38[0-1]$ & $38 \%$ \\
\hline & Chr. Arm & $1.46[0-5]$ & $77 \%$ & $0.85[0-4]$ & $54 \%$ & 0.39 [0-2] & $23 \%$ \\
\hline & Segmental & 3.23 [0-9] & $69 \%$ & $0.77[0-4]$ & $38 \%$ & $0.85[0-4]$ & $31 \%$ \\
\hline \multirow[t]{3}{*}{ All GIST $(n=22)$} & Whole chr. & $1.5[0-6]$ & $64 \%$ & $9.45[0-43]$ & $45 \%$ & $1.72[0-12]$ & $45 \%$ \\
\hline & Chr. Arm & $0.86[0-5]$ & $45 \%$ & $1.78[0-5]$ & $73 \%$ & $0.86[0-3]$ & $36 \%$ \\
\hline & Segmental & $2.45[0-10]$ & $50 \%$ & $4.54[0-35]$ & $64 \%$ & $1.59[0-7]$ & $36 \%$ \\
\hline
\end{tabular}

The minimum and maximum numbers of chromosome aberrations in tumors are indicated in the brackets. Chr - chromosome, $\mathrm{Nb}$ - number.

Table 2 Genes mapping in regions with significant bi-allelic deletions and amplifications

\begin{tabular}{|c|c|}
\hline Chromosome & Genes localized in bi-allelic deleted regions \\
\hline 1 & $\begin{array}{l}\text { AGBL4 (2), AHDC1, AMY1A, AMY2A, AMY1B, AMY2B, } \\
\text { AMY1C, C1orf174, CEP104, DFFB, FAM76A, FGR, IFI6, } \\
\text { RNPC3, STX12, WASF2 }\end{array}$ \\
\hline 2 & LRP1B (3) \\
\hline 3 & FAM86D, FRG2C, LMLN \\
\hline 6 & $\begin{array}{l}\text { AGER, AGPAT1, ATF6B, BTNL24B, CREBL1, CYP21A2, } \\
\text { CHCG4P6, EGFL8, FKBPL, HCG2P7, HLA-DQA1 (3), } \\
\text { HLA-DQA2, HLA-DQB1 (3), HLA-DQB2, HLA-DRA, } \\
\text { HLA-DRB1 (3), HLADRB5 (6), HLA-H, GPSM3, NOTCH4, } \\
\text { PBX2, PPT2, PRRT1, RAGE, RNF5, STK19, TNXB }\end{array}$ \\
\hline 8 & ADAM5P (6), ADAM3A (6) \\
\hline 9 & $\begin{array}{l}\text { CDKN2A (4), CDKN2B (3), DMRTA1, FNBP1, MTAP, } \\
\text { TUSC1 }\end{array}$ \\
\hline 10 & PTEN \\
\hline 11 & ELP4 (2) \\
\hline 14 & $\begin{array}{l}\text { BAZ1A, FAM177A1, IGBP1P1, PPP2R5E (2), PPPR2R3C, } \\
\text { SGPP1 (2), SRP54, WDR89 (2) }\end{array}$ \\
\hline 15 & A26B1 (2), GOLGA8A, PWRN2 \\
\hline 22 & CRYBB2, IGLL3, LRP5L \\
\hline Chromosome & Genes localized in amplified regions \\
\hline 4 & $\begin{array}{l}\text { ANAPC4, CCDC149, CCKAR, LGI2, LOC389203, PCDH7, } \\
\text { PI4K2B, RBPJ, SEPSECS, SLC34A2, SOD3, STIM2, } \\
\text { TBC1D19, ZCCHC4 }\end{array}$ \\
\hline 5 & FGF10 \\
\hline 7 & ZNF680 \\
\hline 8 & ADAM3A, ADAM2 \\
\hline 11 & JRKL, CNTN5, TRIM48 \\
\hline 19 & LOC642290 \\
\hline
\end{tabular}

The number of GISTs with the identified gene deletion is indicated in the brackets. The number of GISTs is not indicated when the gene is deleted in only one tumor. Genes with functions implicating them in GIST oncogenesis are shown in bold. rather than true bi-allelic deletion. Also, the highly polymorphic region in chromosome 6 manifested frequent deletion of genes coding for proteins of the immune system response.

Amplification was a rare genetic event in our series of GISTs. Only 34 amplified regions were detected, and only nine of these were considered to be important (longer than $100 \mathrm{~kb}$ or containing more than $30 \mathrm{SNP}$ ) (Table 2). Even in these cases, the level of amplification was not very high (5-8 copies).

\section{CDKN2A and CDKN2B breakpoint analysis}

For the 9p chromosome region spanning $C D K N 2 A$ and $C D K N 2 B$, we confirmed with precision the location of the allelic breakpoints. Several breakpoints were mapped within the $C D K N 2 A$ and/or $C D K N 2 B$ loci (9p21), so we quantified the number of DNA copies by quantitative multiplex PCR of short fluorescent fragments (QMPSF) within this region. Allelic breakpoints detected in four patients (\#3C2, \#5C3, \#18C3, \#27s2) by SNP arrays analysis were confirmed by QMPSF (Figure 3). Four control patients without breakpoints were studied by QMPSF: no DNA copy number alteration was detected in the region analyzed.

\section{Correlations of chromosomal 4 alterations with WT KIT deletion}

The KIT exon 11 mutations in the 22 patients consisted of 14 deletions, five substitutions, two complex mutations (delins) and one insertion (Table 3). Based on length analysis of PCR products or Sanger sequences, 11 patients were initially considered as having a loss of WT KIT: nine of these 11 patients (81\%) had a cnLOH, which involved the entire $4 \mathrm{q}$ in eight cases; the two other cases had a monosomy and a gain of $4 \mathrm{q}$ with $\mathrm{LOH}$. The proportion of GISTs with $\mathrm{cnLOH}$ involving an entire chromosome arm was higher among tumors 


\begin{tabular}{|c|c|c|c|c|c|c|c|c|c|c|}
\hline \multirow[t]{2}{*}{ Sample } & & \multirow[t]{2}{*}{ MIR 31} & \multirow{2}{*}{$\begin{array}{l}\text { MTAP } \\
\text { exon } 8\end{array}$} & \multicolumn{4}{|c|}{ CDKN2A } & \multicolumn{2}{|c|}{ CDKN2B } & \multirow[t]{2}{*}{ DMRTA1 } \\
\hline & & & & exon 3 & exon 2 & exon $1 \alpha$ & exon $1 \beta$ & exon 2 & exon 1 & \\
\hline \multirow{2}{*}{$1 C 2$} & SNP/CNV & & & & & & & & & \\
\hline & QMPSF & 0.91 & 1.00 & 1.03 & 0.94 & 0.96 & 1.06 & 0.98 & 0.88 & 1.00 \\
\hline \multirow{2}{*}{$3 \mathrm{C} 3$} & SNP/CNV & & ni & & & & & & & \\
\hline & QMPSF & 0.91 & 1.01 & 0.48 & 0.51 & 0.52 & 0.55 & 0.52 & 0.55 & 1.00 \\
\hline \multirow{2}{*}{$5 C 3$} & SNP/CNV & & & & & & & & & \\
\hline & QMPSF & 0.88 & 0.51 & 0.45 & 0.49 & 0.51 & 0.49 & 0.50 & 0.50 & 1.00 \\
\hline \multirow{2}{*}{$6 C 3$} & SNP/CNV & & & & & & & & & \\
\hline & QMPSF & 0.89 & 1.02 & 0.90 & 0.96 & 0.96 & 0.94 & 0.93 & 0.97 & 1.00 \\
\hline \multirow{2}{*}{$18 \mathrm{C} 3$} & SNP/CNV & & & & & & & & & \\
\hline & QMPSF & 0.94 & 0.92 & 0.78 & 0.87 & 0.00 & 0.00 & 0.00 & 0.00 & 1.00 \\
\hline \multirow{2}{*}{$27 S 2$} & SNP/CNV & & & & & & & & & \\
\hline & QMPSF & 0.92 & 1.00 & 0.73 & 0.74 & 0.74 & 0.78 & 0.78 & 0.73 & 1.00 \\
\hline \multirow{2}{*}{$28 S 2$} & SNP/CNV & & & & & & & & & \\
\hline & QMPSF & 0.87 & 0.94 & 0.78 & 0.86 & 0.86 & 0.95 & 0.99 & 0.94 & 1.00 \\
\hline \multirow{2}{*}{$29 S 2$} & SNP/CNV & & & & & & & & & \\
\hline & QMPSF & 0.90 & 0.97 & 0.81 & 0.86 & 0.85 & 0.95 & 0.94 & 0.92 & 1.00 \\
\hline & Legends: & & 2 Copies - I & rozygous & & & & & & \\
\hline & & & 2 copies $-\mathrm{H}$ & ozygous & & & & & & \\
\hline & & & I copy & & & & & & & \\
\hline & & & copy & & & & & & & \\
\hline & & & not inter & & & & & & & \\
\hline
\end{tabular}

Figure 3 Localization of allelic breakpoints as determined from the SNP array and QMPSF in the CDKN2A/CDKN2B genes. In case \#3C2, \#5C3 and \#18C3, the copy number varied within this locus according to SNP analysis, and was confirmed by QMPSF. For QMPSF quantification, DMRTA1 was used as a control gene.

with loss of WT KIT (91\% of GISTs) than those retaining the WT allele $(27 \%$ of GISTs $)(\mathrm{P}<0.05)$.

\section{Overall and progression free survival analysis}

Progression-free survival and overall survival curves were first compared between KIT mutated/KIT WT- $(\mathrm{n}=11)$ and KIT mutated/KIT WT $+(\mathrm{n}=11)$ groups of patients, and then between polyGISTs $(n=9)$ and biGISTs $(n=13)$. No significant differences were observed between any of the groups analyzed $(P>0.5)$ (Additional file 4: Figure $S 2$, Additional file 5: Figure S3).

\section{Discussion}

We performed a whole genome analysis of 22 GISTs with SNP and CGH arrays, and detected numerous different chromosome alterations in most patients. Most of these alterations affected whole chromosomes or chromosome arms. These alterations consisted of gains, losses and $\mathrm{cnLOH}$. We also identified the most frequently altered overlapping regions that may contain genes involved in GIST tumorigenesis. We also describe the presence of bi-allelic deletions and rare amplifications.

Chromosome alterations in GIST have previously been studied by classic cytogenetics [12,13,16,27], CGH arrays [28] and SNP arrays [29]. These studies demonstrated that gains and losses of whole $\mathrm{C} / \mathrm{CA}$ are frequent events in GISTs. Gains frequently involve chromosomes 5 and 8 , whereas most losses affect 1p, 14, 15 or 22 [12,13,15-21]. Our work with high density SNP arrays, CGH arrays and FISH on 22 GISTs with KIT exon 11 mutations confirms these data. Losses were detected in 14/22 (63\%) tumors. The most frequently involved chromosomes/chromosome arms were $14(\mathrm{n}=50 \%), 22(\mathrm{n}=41 \%), 1 \mathrm{p}(\mathrm{n}=36 \%)$ and $15(\mathrm{n}=27 \%)$, which is in accordance with previously published data [18]. Some of these chromosomal alterations have been linked to tumor location [28] and some studies suggest that they may have prognostic significance $[16,18-20]$. The tumors we studied could be classified into two groups with numerous or few chromosomes variations. The 'numerous chromosome variations' phenotype has been described as chromosome instability, and may be related to mutations in a driver gene [30]. It has been reported to be associated with a poor prognosis, but our analysis failed to confirm this possibility.

An important finding of our study is the detection of frequent $\mathrm{cnLOH}$ in GISTs. The phenomenon of $\mathrm{cnLOH}$ was first described as uniparental disomy (UPD) [31], and is responsible for parental imprinting in some inherited conditions, such as Prader-Willi syndrome [32]. The identification of somatic cnLOH (or "acquired UPD") in tumors was more recent [33]. High-density SNP arrays are now available and can be used for analysis of both SNP-based genotype and DNA copy number allowing the detection of cnLOH, which was undetectable by cytogenetic methods. Such cnLOH is a frequent chromosomal alteration in human hematological malignancies, such as leukemia [34], mantle cell lymphomas [35] and follicular lymphoma [36]. For cases of hematological malignancy, samples can be enriched in tumor cells by flow cytometry, making this type of analysis suitable for these diseases. Loss of a WT allele or cnLOH were previously reported in GISTs with mutations in exon 9 of KIT $[29,37,38]$, and $\mathrm{cnLOH}$ was described in a few series of breast [39], endometrial [40], and colorectal carcinomas [41]. However, the frequency of $\mathrm{cnLOH}$ in solid tumors may have been underestimated because the percentages of tumor cells in the samples analyzed were low. By contrast, 
Table 3 Clinico-pathological and genetic data for 22 GISTs

\begin{tabular}{|c|c|c|c|c|c|c|c|c|c|c|}
\hline $\begin{array}{l}\text { Tumor } \\
\text { name }\end{array}$ & Sex & $\begin{array}{l}\text { Age at } \\
\text { diagnosis }\end{array}$ & $\begin{array}{l}\text { Tumor } \\
\text { location* }\end{array}$ & $\begin{array}{l}\text { KIT WT } \\
\text { status** }\end{array}$ & KIT Mutation & $\begin{array}{c}\text { Stage at } \\
\text { diagnosis*** }\end{array}$ & Fletcher $* * * *$ & Histology $* * * *$ & $\begin{array}{l}\text { Mitotic } \\
\text { Index/ } \\
50 \mathrm{HPF}\end{array}$ & $\begin{array}{c}\text { Complementary } \\
\text { analysis }\end{array}$ \\
\hline $1 C 2$ & M & 53 & Sm & WT- & $\begin{array}{l}\text { c.1653_1661del, } \\
\text { p.552-554del }\end{array}$ & L & NA & $\mathrm{F}$ & $>10$ & $\mathrm{CGH}, \mathrm{FISH}$ \\
\hline $3 C 2$ & M & 59 & Ga & WT- & $\begin{array}{l}\text { c.1653_1670del, } \\
\text { p.552_557del }\end{array}$ & M & $H R$ & M & $>10$ & $\mathrm{CGH}$ \\
\hline $4 C$ & $\mathrm{~F}$ & 42 & D & WT- & $\begin{array}{l}\text { c.1708_1728del, } \\
\text { p.570-576del }\end{array}$ & $\mathrm{R}$ & LR & $\mathrm{F}$ & 0 & $\mathrm{CGH}$ \\
\hline $6 C 3$ & M & 67 & $\mathrm{R}$ & WT- & $\begin{array}{l}\text { c.1648-5_1670del, } \\
\text { p.550-558del }\end{array}$ & R & $\mathrm{HR}$ & E & $>10$ & $\mathrm{CGH}$ \\
\hline $18 C 3$ & $\mathrm{~F}$ & 47 & Sm & WT- & $\begin{array}{l}\text { c.1679 T > A } \\
\text { p.V560D }\end{array}$ & $\mathrm{R}$ & NA & $\mathrm{F}$ & $>10$ & $\mathrm{CGH}$ \\
\hline $20 s 2$ & M & 57 & Ga & WT- & $\begin{array}{l}\text { c.1666_1680del, } \\
\text { p.556_560del }\end{array}$ & M & $H R$ & $\mathrm{~F}$ & $>10$ & $\mathrm{CGH}, \mathrm{FISH}$ \\
\hline $28 s 2$ & $\mathrm{~F}$ & 57 & D & WT- & $\begin{array}{l}\text { c.1679_1681del, } \\
\text { p.560del }\end{array}$ & R & NA & $\mathrm{F}$ & NA & NR \\
\hline $29 \mathrm{~s} 2$ & M & 60 & Ga & WT- & $\begin{array}{l}\text { c.1669_1674del, } \\
\text { p.557_558del }\end{array}$ & $\mathrm{R}$ & $\mathrm{HR}$ & M & $>10$ & $\mathrm{CGH}$ \\
\hline 30 s2 & M & 85 & M & WT- & $\begin{array}{l}\text { c1669 T>A } \\
\text { pW557R }\end{array}$ & L & $H R$ & $\mathrm{~F}$ & $>10$ & $N R$ \\
\hline 31 s2 & M & 53 & Sm & WT- & $\begin{array}{l}\text { c1658-1669del, } \\
\text { p.553-556del }\end{array}$ & M & $\mathrm{HR}$ & $\mathrm{F}$ & $>10$ & NR \\
\hline 32 s2 & $\mathrm{F}$ & 43 & Sm & WT- & $\begin{array}{l}\text { c1670-1675Del, } \\
\text { p.557_559delinsF }\end{array}$ & NA & NA & $\mathrm{F}$ & 2 & NR \\
\hline $2 \mathrm{P} 2$ & M & 82 & Ga & WT+ & $\begin{array}{l}\text { c.1670_1675del, } \\
\text { p.557_559delinsF }\end{array}$ & M & $H R$ & $\mathrm{~F}$ & $>10$ & NR \\
\hline $5 C 3$ & $\mathrm{~F}$ & 64 & $\mathrm{D}$ & WT+ & $\begin{array}{l}\text { c.1669_1716del, } \\
\text { p.557-572del }\end{array}$ & $\mathrm{R}$ & $H R$ & M & NA & $N R$ \\
\hline $10 C 2$ & M & 66 & Sm & $\mathrm{WT+}$ & $\begin{array}{l}\text { c.1669_1674del, } \\
\text { p.557_558del }\end{array}$ & $\mathrm{R}$ & $\mathrm{HR}$ & $\mathrm{F}$ & $>10$ & NR \\
\hline $14 C 2$ & $\mathrm{~F}$ & 60 & Ga & WT+ & $\begin{array}{l}\text { c.1679_1681del, } \\
\text { p.560del }\end{array}$ & R & $H R$ & $\mathrm{~F}$ & 2 & NR \\
\hline $15 C 2$ & $\mathrm{~F}$ & 54 & Sm & WT+ & $\begin{array}{l}\text { c.1676 T>G, } \\
\text { p.V559G }\end{array}$ & R & $\mathbb{R}$ & $\mathrm{F}$ & 1 & FISH \\
\hline $22 s 2$ & $\mathrm{~F}$ & 54 & $\mathrm{Ga}$ & WT+ & $\begin{array}{l}\text { c.1679 T>G, } \\
\text { p.V560G }\end{array}$ & NA & $L R$ & $\mathrm{~F}$ & 1 & $N R$ \\
\hline 23 s2 & $\mathrm{F}$ & 45 & Ga & WT+ & $\begin{array}{l}\text { c.1658_1674delinsCTGAA, } \\
\text { p.553-558delinsSE }\end{array}$ & NA & $L R$ & $\mathrm{~F}$ & 0 & $N R$ \\
\hline $24 s 2$ & $\mathrm{~F}$ & 57 & D & WT+ & $\begin{array}{l}\text { c.1673_1674insTCC, } \\
\text { p.558delinsNP }\end{array}$ & R & $L R$ & $\mathrm{~F}$ & 0 & $\mathrm{CGH}$ \\
\hline $12 \mathrm{C} 2$ & M & 39 & Ga & WT+ & $\begin{array}{l}\text { c.1700_1726delinsGTTGTG, } \\
\text { p.567-576SdelinSCV }\end{array}$ & $\mathrm{R}$ & HR & $E$ & 0 & NR \\
\hline 19 s2 & M & 55 & Ga & WT+ & c.1679 T > A, p.V560D & $\mathrm{R}$ & $H R$ & E & $>10$ & $\mathrm{CGH}$ \\
\hline $27 s 2$ & M & 59 & Ga & WT+ & $\begin{array}{l}\text { c.1669_1680del, } \\
\text { p.557-560del }\end{array}$ & $\mathrm{R}$ & $\mathrm{HR}$ & $M$ & $>10$ & $\mathrm{CGH}$ \\
\hline
\end{tabular}

*Sm: small intestine; Ga: gastric; D: duodenum; M: mesenteric; R: rectum.

**WT-: loss of wild type allele of KIT; WT+: presence of the wild type allele of KIT.

***L: localy advanced; M: metastatic; R: resectable.

****According to Fletcher classification: HR: High risk; LR: low risk; IR: intermediate risk.

*****F: spindled cells; E: epithelioid form: M: mixed form.

NA - not available, NR - not realized.

the contamination of GISTs with non-tumor cells is generally low, and in the present study, more than $95 \%$ of all samples were tumor cells. Additional studies using algorithms adapted to low tumor percentage [42] are needed to determine whether $\mathrm{cnLOH}$ is also frequent in other human solid tumors. 
Two main types of cnLOH have been observed: whole $\mathrm{C} / \mathrm{CA}$ and segmental $\mathrm{cnLOH}$ (telomeric or interstitial). Various mechanisms can lead to $\mathrm{cnLOH}$ and are probably different for these two types [43]. Whole C/CA $\mathrm{cnLOH}$ may result from the loss of a chromosome/ chromosome arm followed by chromosomal duplication of the paired chromosome/chromosome arm, or from a non-disjunction event during mitosis followed by loss of the supernumerary chromosome/chromosome arm. Segmental cnLOH can be secondary to a homologous somatic recombination: this seems to be the major mechanism responsible for $\mathrm{cnLOH}$ in hematological malignancies [44] but still not well understood; it may be a cellular attempt to correct a deletion or repair double-strand breaks in the DNA. We show here that in GISTs, most cnLOH were whole C/CA type. Furthermore, all biGISTs with $\mathrm{cnLOH}$ also had losses of chromosome arms. The $\mathrm{cnLOH}$ in GISTs may be due to a loss of chromosome material during mitosis followed by duplication of the paired material. This hypothesis is controversial, and other studies have described cnLOH in GISTs as being mostly segmental, suggesting mitotic recombination as the major mechanism of $\mathrm{cnLOH}$ [45]. Different inclusion criteria of tumors samples as well as different normalization and datamining methods used in this study and in previously published data may in part cause these disparate observations.

The pathogenic consequences of $\mathrm{cnLOH}$ in cancer are multiple; it may give rise to homozygosity for a mutated tumor suppressor gene promoting tumor growth or chemotherapy resistance. Homozygosity may also change the methylation equilibrium of regulatory regions and result in epigenetic modulation of oncogenic pathways. Recently, cnLOH was observed in approximately $40 \%$ of patients with relapsed acute myeloid leukemia [44] suggesting that it may be a mechanism for cancer progression in many cases. It has been reported that $\mathrm{cnLOH}$ is associated with JAK2 or FLT3 internal tandem duplication with oncogenic mutations in acute myeloid leukemias $[44,46]$ and may also contribute to inactivating tumor suppressor genes in colorectal cancer, for example $h M L H 1$ [47]. Homozygosity of JAK2 V617F and of FLT3 mutations is associated with a poorer prognosis of patients with leukemia or myeloproliferative disorders $[46,48]$.

One of our aims was to determine the causes of the KIT mutation "homozygosity" observed in some GISTs. We detected $\mathrm{cnLOH}$ in chromosome $4 \mathrm{q}$ in 9/11 GISTs with KIT WT allele loss (81\% of cases), whereas only one case showed $\mathrm{LOH}$ associated with $4 \mathrm{q}$ monosomy; the other case had a gain of $4 \mathrm{q}$ with loss of the KIT WT allele. Thus, KIT mutation homozygosity is due to $\mathrm{cnLOH}$ in most GISTs. GISTs with homozygous mutations of KIT have been reported to have a poor prognosis in a small number of independent series [23,26], although, in our series, there was no correlation with survival. However, our series was designed for molecular analyses: we specifically enriched the population with GISTs with a loss of WT KIT, and those with mutated KIT/WT KIT were selected mainly to match the type of KIT exon 11 and are thus not representative of GISTs in general. Large unbiased series are required to correlate $\mathrm{cnLOH}$, gain of $4 \mathrm{q}$ and/or "homozygous" KIT mutations with clinical characteristics and survival. The absence of matched blood samples may be responsible for the false positive detection of $\mathrm{cnLOH}$ that coincide with inherited regions of homozygosity. However, the risk of false positives is mainly associated with small segments of partial $\mathrm{cnLOH}$; the risk is therefore relatively small in our series of GISTs as almost all the cnLOH detected were large.

In addition to chromosome instability, we detected numerous genomic alterations including bi-allelic deletions and amplifications. By using quantitative real-time PCR for sequences in the 9p21 region, we confirmed, with precision, the sites of the breakpoints detected with SNP arrays. We reported significant complete deletions of 48 regions involving numerous different genes; this thus implicates some of these genes in carcinogenesis, particularly those with functions in the cycle cell, DNA repair or apoptosis. Some of these genes with bi-allelic deletions map in common overlapping regions frequently altered in our series (CDKN2A, CDKN2B, TUSC1), providing further arguments in favor of them having a role in GIST oncogenesis. Deletion of CDKN2A in GISTs has already been reported, and is associated with a poor prognosis [13]. Functional studies are necessary to determine whether the abnormalities of some of these genes may be responsible for, rather a consequence of, the substantial chromosomal instability of GISTs.

\section{Conclusions}

Our whole genome analysis confirms that GISTs display chromosomal instability involving whole chromosomes and/or chromosome arms. Two main types of chromosomal instability were observed: abundant gains and $\mathrm{cnLOH}$, and their occurrence was independent in this series. There were numerous cases of $\mathrm{cnLOH}$, which was responsible for KIT exon 11 mutation homozygosity. Several potential tumor driver genes were also detected. Functional studies are necessary to determine whether some of these gene anomalies are responsible for, rather than a consequence of, the high chromosomal instability of GISTs.

\section{Materials and methods Patients}

KIT-positive GISTs carring mutations in exon 11 of KIT were selected from the Ambroise Paré hospital tissue bank database. All patients with loss of the WT KIT 
allele were included ( 25 samples) if there was sufficient frozen or paraffin-embedded material. Eleven tumors with heterozygous KIT exon 11 mutations were used as controls.

All GIST patients included in this genotyping analysis had previously participated in the MolecGIST study [5]. Participants in MolecGIST provided their verbal informed consent to participate in this study after reading an information note. MolecGIST was approved by the appropriate French ethics committee: "Comité pour la Protection des Personnes se prêtant à des Recherches Biomédicales" (CPPRB, Committee for the Protection of Persons suitable for Biomedical Research) Saint Germain en Laye \#06029, April 24th 2006.

All relevant information about the patients and tumor samples is given in Table 3 . The median age of the 22 patients was 57 years (range [39 to 85]), and there were 12 men and 10 women. GISTs were localized in stomach $(n=10)$, duodenum $(n=4)$, small intestine $(n=6)$, rectum $(\mathrm{n}=1)$ and mesentery $(\mathrm{n}=1)$. Most samples analyzed were obtained from primary tumors, except for the samples from patients \#32 s2 and \#2P2 (metastases), and \#1C2, \#18C3 (intra-abdominal relapse). One sample was obtained after treatment with imatinib (\#18C3). The types of exon $11 \mathrm{mu}-$ tations are described in Table 3. According to the Fletcher classification estimating malignancy potential, 13 tumors were at high risk, two at intermediate risk, and three at low risk; for four samples the relevant information was not available. The mitotic count was higher than 10/50 HPF for 12 samples, between 5 and 10/50 HPF for one sample and less than 5/50 HPF for eight samples; the mitotic count was not known for one sample.

\section{DNA extraction}

Genomic DNA was extracted from either frozen or paraffin-embedded fragments of GIST as previously described [22]. Histological control with hematoxylin \& eosin staining was performed on each sample before and after cutting the slides for DNA extraction. Tissue samples were macrodissected, and at least $90 \%$ of the cells in the samples used for DNA extraction were tumor cells. DNA samples were analyzed with a spectrophotometer (ND-100, Nanodrop ${ }^{\oplus}$ ) and by electrophoresis, and only samples with a molecular weight higher than $2,5 \mathrm{~Kb}$ were selected for SNP arrays.

\section{Identification of KIT mutation}

The method for identification of KIT mutation has been described previously [49]. Relative amounts of WT and mutated alleles of KIT in patients with deletions or insertions were determined by analysis of fluorescent PCR products, and loss of WT KIT was defined as a [mutated/ wild type] ratio higher than 1.5 [23]. Patients with a single nucleotide substitution mutation were considered as homozygous, if the WT nucleotide peak was at least three times lower than that the mutant peak in both forward and reverse Sanger sequences.

\section{Whole genome analysis}

GIST DNA samples were hybridized on Human370CNVQUAD SNP arrays (Infinium Ilumina ${ }^{\circ}$ ) according to the manufacturer's instructions by IntegraGen (Evry, France). This array contains over 370000 probes distributed throughout the genome with a median coverage of one probe every 5000 bases. However, the array does not include chromosome 13p, 14p, 15p, 21p or 22p markers. Chromosomes $\mathrm{Y}$ and $\mathrm{X}$ were only used to verify the sex of the patient. All genome positions were based upon NCBI36/hg18 from UCSC Genome Bioinformatics.

The fluorescence intensity data extracted using Illumina's BeadScan software was analyzed twice by two different methods. In the first approach, the intensity data were normalized as described by Illumina Inc [50] with IntegraGen commercial platform assistance. SNP genotyping data was plotted in Illumina Genome Viewer and Chromosome Browser of Illumina's BeadStudio3.0 (Illumina Inc., San Diego, CA, USA) that chromosome aberrations were visualized and identified in respect to their localization. Regions with $\mathrm{B}$ allele Freq values and $\mathrm{LOH}$ Score suggestive of $\mathrm{LOH}$ without the modification in $\log \mathrm{R}$ values were considered as cnLOH segments. However, normalization and data-mining of Illumina platform was originally designed for genotyping of normal genomes. In the second analysis, the genotyping data were normalized and analyzed with tQN8 and GAP methods $[51,52]$ by the biostatistics platform of la Ligue contre le Cancer. tQN8 normalization strategy was showed to improve the quality of Illumina arrays data of cancer genomes when used for LOH and copy number variations studies [51]. GAP method was also developed for complex cancer genomes to analyze segmental copy numbers, genotype status and overall genomic ploidy of tumors [52]. Additionally, CNA and AD were visually investigated on BeadStudio software (version3) by two independent researchers. Chromosome aberrations containing 30 SNP or more and/or longer than $100 \mathrm{~kb}$ were considered as true. Chromosome abnormalities were compared between tumors to detect the most frequently altered common overlapping regions (present in $>20 \%$ of tumors). For tumors with ploidy higher than two, gains and losses were defined according to their ploidy level in this analysis. For tumors with chromosome numbers near 46, 69 and 92, the presence of more than four, five and six copies, respectively, were considered to be amplifications.

IntegraChipTM (CIT-CGH Homo sapiens BAC) arrays were hybridized with tumor DNA from 10 patients by the IntegraGene commercial platform according to the manufacturer's instructions. 
The results for 22 of the 36 samples hybridized on SNP arrays were of sufficient quality for analysis. Only 1 of the 13 arrays obtained with DNA extracted from paraffinembedded tissue was of acceptable quality, whereas $21 / 23$ samples from frozen tissue were satisfactory. The median call rate of the 22 samples was $98 \%$ (range [0.93 to 0.998]).

\section{Quantitative Multiplex PCR of Short Fluorescent Fragments (QMPSF) analysis}

QMPSF is a sensitive method involving the simultaneous amplification of short genomic fragments using dye-labeled primers under quantitative conditions, and was used for the detection of 9 p21 genomic deletions. The assay employed ten primer pairs that cover a $2.8 \mathrm{Mb}$ region and five genes (Telomere > MIR31/MTAP/CDKN2A/CDKN2B/DMRTA1 > Centromere) located in the $9 \mathrm{p} 21$ locus and generates PCR fragments of 150 to 250 base pairs. PCR conditions for QMPSF analyses of CDKN2A and CDKN2B loci have been described previously [53]. Briefly, 100 ng of genomic DNA was used in a final volume of $25 \mathrm{uL}$ with $0.16 \mathrm{mmol} / \mathrm{L}$ of each deoxynucleoside triphosphate, $1.5 \mathrm{mmol} / \mathrm{L} \mathrm{MgCl}_{2}, 1$ unit of thermoprime Plus DNA polymerase (ABgene), 5\% dimethyl sulfoxide and 0.5 to $1.6 \mathrm{mmol} / \mathrm{L}$ of each primer, one primer of each pair carrying a 6-carboxyfluorescein label. After an initial denaturation for $3 \mathrm{~min}$ at $94^{\circ} \mathrm{C}, 20 \mathrm{cy}-$ cles were performed consisting of denaturation at $94^{\circ} \mathrm{C}$ for $15 \mathrm{~s}$, annealing at $90^{\circ} \mathrm{C}$ for $15 \mathrm{~s}$ (ramping $3^{\circ} \mathrm{C} / \mathrm{s}$ ) and extension at $70^{\circ} \mathrm{C}$ for $15 \mathrm{~s}$ (ramping $3^{\circ} \mathrm{C} / \mathrm{s}$ ), followed by a final extension step for $5 \mathrm{~min}$ at $70^{\circ} \mathrm{C}$. PCR products were analyzed on a sequencing platform used in the fragment analysis mode in which both peak heights and areas are proportional to the quantity of template present for each target sequence.

\section{FISH}

Imprints of GISTs cells were obtained with briefly defrosted tumor samples. For each sample, one slide was stained with Giemsa for cytological control. Two centromere probes, one for each chromosomes 4 and 18 (CEN4, CEN18) (Kreatech Biotechnology) were used and six BAC probes RP11-93 L18, RP11-983 F2 (chr17), RP11-959 K5, RP11642 F17 (chr22), RP11-586A2 (chr4) and RP-11-121G9 (chr7) - were produced: bacteria carrying a BAC vector were grown overnight on solid agar medium, and then cultured overnight in LB medium. BAC DNA was extracted using NucleoBond PC 500 or NucleoBand Xtra BAC Kits (Macherey-Nagel) as recommended by producer. Aliquots of $1 \mu \mathrm{g}$ of DNA were labeled by nick-translation according to the kit manufacturer's instructions (Nick Translation Kit, Abott). The labeled DNA (the probe) was precipitated by incubation overnight at $-20^{\circ} \mathrm{C}$ in the presence of human cot DNA, sodium acetate and ethanol, and then resuspended in hybridization buffer (LSI/WCP Hybridization Buffer, Abott). The probes were used at a final concentration of 40-50 $\mathrm{ng} / \mu \mathrm{L}$. Commercial probes were applied according to the manufacturer's recommendations (Kreatech Biotechnology). Co-denaturation of the probes and the tumor section were performed to create single-stranded DNA. Fluorescence signals were analyzed using a Leica DM4000B microscope equipped with appropriate filters and a 22 DFC300FX camera under the control of LAS V4.0 software (Leica). The fluorescence signals in at least 10 nuclei were counted.

\section{Statistical analysis}

Survival curves were estimated using the Kaplan-Meier method, and differences between curves were assessed using the log-rank test. The threshold for significance was set at a p-value of 5\%. The analysis was conducted using R software (2.14.1). Progression-free survival (PFS) is defined as the time interval between surgery and first evidence of disease progression or relapse. Overall survival (OS) is defined as the time interval between GIST diagnosis and death or last news. T-tests were used as appropriate.

\section{Additional files}

Additional file 1: Figure S1. CGH array karyotyping data for 10 GISTs. Chromosome copy number state: deletions (green), gains (red), two copies (white). Chromosomes are indicated in the first column on the left.

Additional file 2: Table S1. Cytogenetic findings and $\mathrm{cnLOH}$ data detected for 22 GISTs.

Additional file 3: Table S2. Identification of common genetic alterations in 22 GISTs: chromosome aberrations longer than 100 kb and/or containing 30 SNP or more were included. Regions of chromosome loss and gain are represented by chromosome numbers on green and red backgrounds, respectively.

Additional file 4: Figure S2. Overall survival (OS) curves for patients with GISTs. A) Overall survival curves according to polyploidy level. No significant difference in OS was detected between polyGIST and biGIST groups. B) Overall survival curves according to KIT exon 11 mutation status. No significant difference in OS was detected between homozygous and heterozygous exon 11 mutated groups. WT $+=$ WT allele present, WT- $=$ WT allele loss.

Additional file 5: Figure S3. Progression-free survival (PFS) curves for patients with GISTs. A) Progression-free survival curves according to polyploidy level. There was no significant difference in PFS was observed between polyGISTs and biGISTs groups. B) PFS curves according to KIT exon 11 mutation status. There was no significant difference in PFS between homozygous and heterozygous exon 11 mutated groups. WT $+=$ WT allele present, $\mathrm{WT}-=\mathrm{WT}$ allele loss.

\section{Competing interests}

The authors declare that they have no competing interests.

\section{Authors' contributions}

Conception and design: NL, ZHR, JFE. Development of the methodology, Acquisition of data: NL, ZHR, JBB, SBA, FJ, JTN, FP, EM, FC, JFE; Analysis and interpretation of data: NL, ZHR, JBB, SBA, FJ, JTN, FP, EM, AB, FC, JFE; Writing and revision of the manuscript: NL, ZHR, JFE; Study supervision: JEF; All authors have read and approved the final manuscript. 


\section{Acknowledgments}

Z. Hélias-Rodzewicz received a fellowship from the Institut National du Cancer (TAKIMAGI). This work was supported in part by the non-profit organization AREP.

We thank Julien Laffaire for his contribution to statistical analyses, and Yolaine Pothin, Nathalie Terrones and Dominique Péchaud for technical contributions.

\section{Note}

The raw high resolution SNP array data of the 22 gastrointestinal stromal tumors will be made available at the Sequence Read Archive.

\section{Author details}

${ }^{1}$ EA4340, Versailles University, Boulogne-Billancourt, France. ${ }^{2}$ Department of Pathology, Ambroise Paré Hospital, APHP, 9 Avenue Charles de Gaulle, Boulogne-Billancourt, France. ${ }^{3}$ Digestive Oncology Unit, Pitié Salpétrière Hospital, APHP, Paris, France. ${ }^{4}$ Centre Henri Becquerel, INSERM U918, Université de Rouen, Rouen, France. ${ }^{5}$ Department of Pathology, Henri Mondor Hospital, APHP, Créteil, France. ${ }^{6}$ Department of Surgery, Ambroise Paré Hospital, APHP, Boulogne-Billancourt, France. ${ }^{7}$ Integragen, Evry, France. ${ }^{8} \mathrm{Clinical}$ Research Unit, Ambroise Paré Hospital, APHP, Boulogne-Billancourt, France. ${ }^{9}$ Bergonié Institut, INSERM U916, Bordeaux, France. ${ }^{10}$ Present address: Digestive Oncology Unit, Saint Louis Hospital, APHP, Paris, France.

Received: 28 April 2014 Accepted: 23 October 2014

Published: 6 November 2014

\section{References}

1. Cassier PA, Ducimetière F, Lurkin A, Ranchère-Vince $D$, Scoazec JY, Bringuier PP, Decouvelaere AV, Méeus P, Cellier D, Blay JY, Ray-Coquard I: A prospective epidemiological study of new incident GISTs during two consecutive years in Rhône Alpes region: incidence and molecular distribution of GIST in a European region. Br J Cancer 2010, 103:165-170.

2. Hirota S, Isozaki K, Moriyama Y, Hashimoto K, Nishida T, Ishiguro S, Kawano K, Hanada M, Kurata A, Takeda M, Muhammad Tunio G, Matsuzawa Y, Kanakura Y, Shinomura Y, Kitamura Y: Gain-of-fonction mutations of c-kit in human gastrointestinal stromal tumors. Science 1998, 279:577-580.

3. Heinrich MC, Corless CL, Duensing A, McGreevey L, Chen CJ, Joseph N, Singer S, Griffith DJ, Haley A, Town A, Demetri GD, Fletcher CD, Fletcher JA: PDGFRA activating mutations in gastrointestinal stromal tumors. Science 2003, 299:708-710.

4. Rubin BP, Heinrich MC, Corless CL: Gastrointestinal tumour. Lancet 2007, 369:1731-1741.

5. Emile JF, Brahimi $S$, Coindre JM, Bringuier PP, Monges $G$, Samb P, Doucet $L$, Hostein I, Landi B, Buisine MP, Neuville A, Bouché O, Cervera P, Pretet JL, Tisserand J, Gauthier A, Le Cesne A, Sabourin JC, Scoazec JY, Bonvalot S, Corless CL, Heinrich MC, Blay JY, Aegerter P: Frequencies of KIT and PDGFRA mutations in the MolecGIST prospective population-based study differ from those of advanced GISTs. Med Oncol 2012, 29:1765-1772.

6. Demetri $G D$, von Mehren $M$, Blanke CD, Van den Abbeele AD, Eisenberg B, Roberts PJ, Heinrich MC, Tuveson DA, Singer S, Janicek M, Fletcher JA, Silverman SG, Silberman SL, Capdeville R, Kiese B, Peng B, Dimitrijevic S, Druker BJ, Corless C, Fletcher CD, Joensuu H: Efficacy and safety of imatinib mesylate in advanced gastrointestinal stromal tumors. N Engl J Med 2002, 347:472-480.

7. Dematteo RP, Ballman KV, Antonescu CR, Maki RG, Pisters PW, Demetri GD, Blackstein ME, Blanke CD, von Mehren M, Brennan MF, Patel S, McCarter MD Polikoff JA, Tan BR, Owzar K: Adjuvant imatinib mesylate after resection of localised, primary gastrointestinal stromal tumour: a randomised, double-blind, placebo-controlled trial. Lancet 2009, 373:1097-1104.

8. Debiec-Rychter M, Sciot R, Le Cesne A, Schlemmer M, Hohenberger P, van Oosterom AT, Blay JY, Leyvraz S, Stul M, Casali PG, Zalcberg J, Verweij J, Van Glabbeke M, Hagemeijer A, Judson I: KIT mutations and dose selection for imatinib in patients with advanced gastrointestinal stromal tumours. Eur J Cancer 2006, 42:1093-1103.

9. Fletcher JA: Role of KIT and Platelet-derived growth factor receptors as oncoproteins. Semin Oncol 2004, 31:4-11.

10. Corless CL, McGreevey L, Haley A, Town A, Heinrich MC: KIT mutations are common in incidental gastrointestinal stromal tumors one centimeter or less in size. Am J Pathol 2002, 160:1567-1572.
11. Bachet JB, Landi B, Laurent-Puig P, Italiano A, Le Cesne A, Lévy P, Safar V, Duffaud F, Blay JY, Emile JF: Diagnosis, prognosis and treatment of patients with gastrointestinal stromal tumour (GIST) and germline mutation of KIT exon 13. Eur J Cancer 2013, 49:2531-2541.

12. El-Rifai W, Sarlomo-Rikala M, Miettinen M, Knuutila S, Andersson LC: DNA copy number losses in chromosome 14: an early change in gastrointestinal stromal tumors. Cancer Res 1996, 56:3230-3233.

13. Kim NG, Kim JJ, Ahn JY, Seong CM, Noh SH, Kim CB, Min JS, Kim H: Putative chromosomal deletions on $9 p, 9 q$ and $22 q$ occur preferentially in malignant gastrointestinal stromal tumors. Int J Cancer 2000, 85:633-638

14. El-Rifai W, Sarlomo-Rikala M, Andersson LC, Miettinen M, Knuutila S: Highresolution deletion mapping of chromosome 14 in stromal tumors of the gastrointestinal tract suggests two distinct tumor suppressor loci. Genes Chromosomes Cancer 2000, 27:387-391.

15. Breiner JA, Meis-Kindblom J, Kindblom LG, McComb E, Liu J, Nelson M Bridge JA: Loss of $14 q$ and $22 q$ in gastrointestinal stromal tumors (pacemaker cell tumors). Cancer Genet Cytogenet 2000, 120:111-116.

16. El-Rifai W, Sarlomo-Rikala M, Andersson LC, Knuutila S, Miettinen M: DNA sequence copy number changes in gastrointestinal stromal tumors: tumor progression and prognostic significance. Cancer Res 2000, 60:3899-3903

17. Derré J, Lagacé R, Terrier P, Sastre X, Aurias A: Consistent DNA losses on the short arm of chromosome 1 in a series of malignant gastrointestinal stromal tumors. Cancer Genet Cytogenet 2001, 127:30-33.

18. Gunawan B, von Heydebreck A, Sander B, Schulten HJ, Haller F, Langer C, Armbrust T, Bollmann M, Gasparov S, Kovac D, Fuzesi L: An oncogenetic tree model in gastrointestinal stromal tumours (GISTs) identifies different pathways of cytogenetic evolution with prognostic implications. J Pathol 2007, 211:463-470.

19. Chen Y, Liou CP, Tseng HH, Jan YJ, Li CF, Tzeng CC: Deletions of chromosome $1 p$ and $15 q$ are associated with aggressiveness of gastrointestinal stromal tumors. J Formos Med Assoc 2009, 108:28-37.

20. Silva $M$, Veiga I, Ribeiro FR, Vieira J, Pinto C, Pinheiro M, Mesquita B, Santos C, Soares M, Dinis J, Santos L, Lopes P, Afonso M, Lopes C, Teixeira MR: Chromosome copy number changes carry prognostic information independent of KIT/PDGFRA point mutations in gastrointestinal stromal tumors. BMC Med 2010, 8:26.

21. Yamamoto H, Kohashi K, Tsuneyoshi M, Oda Y: Heterozygosity loss at $22 q$ and lack of INI1 gene mutation in gastrointestinal stromal tumor. Pathobiology 2011, 78:132-139.

22. Théou N, Tabone S, Saffroy R, Le Cesne A, Julié C, Cortez A, Lavergne-Slove A, Debuire B, Lemoine A, Emile JF: High expression of both mutant and wild-type alleles of c-kit in gastrointestinal stromal tumors. Biochim Biophys Acta 2004, 1688:250-256.

23. Emile JF, Bachet JB, Tabone-Eglinger S, Terrier P, Vignault JM: GIST with homozygous KIT exon 11 mutations. Lab Invest 2008, 88:456-457.

24. Brahimi-Adouane S, Bachet JB, Tabone-Eglinger S, Subra F, Capron C, Blay JY, Emile JF: Effects of endoplasmic reticulum stressors on maturation and signaling of hemizygous and heterozygous wild-type and mutant forms of KIT. Mol Oncol 2013, 7:323-333.

25. Bachet JB, Tabone-Eglinger S, Dessaux S, Besse A, Brahimi-Adouane S, Emile JF, Blay JY, Alberti L: Gene expression patterns of hemizygous and heterozygous KIT mutations suggest distinct oncogenic pathways: a study in NIH3T3 cell lines and GIST samples. PLoS One 2013, 8:e61103.

26. Lasota J, vel Dobosz AJ, Wasag B, Wozniak A, Kraszewska E, Michej W, Ptaszynski K, Rutkowski P, Sarlomo-Rikala M, Steigen SE, Schneider-Stock R, Stachura J, Chosia M, Ogun G, Ruka W, Siedlecki JA, Miettinen M: Presence of homozygous KIT exon 11 mutations is strongly associated with malignant clinical behaviour in gastrointestinal stromal tumors. Lab Invest 2007, 87:1029-1041.

27. Bergmann F, Gunawan B, Hermanns B, Höer J, Schumpelick V, Füzesi L: Cytogenetic and morphologic characteristics of gastrointestinal stromal tumors. Recurrent rearrangement of chromosome 1 and losses of chromosomes 14 and 22 as common anomalies. Verh Dtsch Ges Pathol $1998,82: 275-278$.

28. Wozniak A, Sciot R, Guillou L, Pauwels P, Wasag B, Stul M, Vermeesch JR, Vandenberghe P, Limon J, Debiec-Rychter M: Array CGH analysis in primary gastrointestinal stromal tumors: cytogenetic profile correlates with anatomic site and tumor aggressiveness, irrespective of mutational status. Genes Chromosomes Cancer 2007, 46:261-276. 
29. Belinsky MG, Skorobogatko YV, Rink L, Pei J, Cai KQ, Vanderveer LA, Riddell D, Merkel E, Tarn C, Eisenberg BL, von Mehren M, Testa JR, Godwin AK: High density DNA array analysis reveals distinct genomic profiles in a subset of gastrointestinal stromal tumors. Genes Chromosomes Cancer 2009, 48:886-896.

30. Lagarde P, Pérot G, Kauffmann A, Brulard C, Dapremont V, Hostein I, Neuville A, Wozniak A, Sciot R, Schöffski P, Aurias A, Coindre JM, Debiec-Rychter $\mathrm{M}$, Chibon F: Mitotic checkpoints and chromosome instability are strong predictors of clinical outcome in gastrointestinal stromal tumors. Clin Cancer Res 2012, 18:826-838.

31. Engel E: A new genetic concept: uniparental disomy and its potential effect, isodisomy. Am J Med Genet 1980, 6:137-143.

32. Mascari MJ, Gottlieb W, Rogan PK, Butler MG, Waller DA, Armour JA, Jeffreys AJ, Ladda RL, Nicholls RD: The frequency of uniparental disomy in Prader-Willi syndrome. Implications for molecular diagnosis. N Engl J Med 1992, 326:1599-1607.

33. Murthy SK, DiFrancesco LM, Ogilvie RT, Demetrick DJ: Loss of heterozygosity associated with uniparental disomy in breast carcinoma. Mod Pathol 2002, 15:1241-1250.

34. Raghavan M, Lillington DM, Skoulakis S, Debernardi S, Chaplin T, Foot NJ, Lister TA, Young BD: Genome-wide single nucleotide polymorphism analysis reveals frequent partial uniparental disomy due to somatic recombination in acute myeloid leukemias. Cancer Res 2005, 65:375-378.

35. Halldórsdóttir AM, Sander B, Göransson H, Isaksson A, Kimby E, Mansouri M, Rosenquist $\mathrm{R}$, Ehrencrona $\mathrm{H}$ : High-resolution genomic screening in mantle cell lymphoma-specific changes correlate with genomic complexity, the proliferation signature and survival. Genes Chromosomes Cancer 2010, 50:113-121.

36. O'Shea D, O'Riain C, Gupta M, Waters R, Yang Y, Wrench D, Gribben J, Rosenwald A, Ott G, Rimsza LM, Holte H, Cazier JB, Johnson NA, Campo E, Chan WC, Gascoyne RD, Young BD, Staudt LM, Lister TA, Fitzgibbon J: Regions of acquired uniparental disomy at diagnosis of follicular lymphoma are associated with both overall survival and risk of transformation. Blood 2009, 113:2298-2301.

37. Chen LL, Holden JA, Choi H, Zhu J, Wu EF, Jones KA, Ward JH, Andtbacka RL, Scaife CL, Hunt KK, Prieto VG, Raymond AK, Zhang W, Trent JC, Benjamin RS, Frazier ML: Evolution from heterozygous to homozygous KIT mutation in gastrointestinal stromal tumor correlates with the mechanism of mitotic nondisjunction and significant tumor progression. Mod Pathol 2008 21:826-836.

38. Kikuchi H, Yamamoto M, Hiramatsu Y, Baba M, Ohta M, Kamiya K, Tanaka T, Suzuki S, Sugimura H, Kitagawa M, Kanai T, Kitayama Y, Kanda T, Nishikura K, Konno H: Effect of loss of heterozygosity of the c-Kit gene on prognosis after hepatectomy for metastatic liver gastrointestinal stromal tumors. Cancer Sci 2007, 98:1734-1739.

39. Tuna M, Smid M, Martens JW, Foekens JA: Prognostic value of acquired uniparental disomy (aUPD) in primary breast cancer. Breast Cancer Res Treat 2012, 132:189-196.

40. Murayama-Hosokawa S, Oda K, Nakagawa S, Ishikawa S, Yamamoto S, Shoji K, Ikeda Y, Uehara Y, Fukayama M, McCormick F, Yano T, Taketani Y, Aburatani H: Genome-wide single-nucleotide polymorphism arrays in endometrial carcinomas associate extensive chromosomal instability with poor prognosis and unveil frequent chromosomal imbalances involved in the PI3-kinase pathway. Oncogene 2010, 23:1897-1908.

41. Darbary HK, Dutt SS, Sait SJ, Nowak NJ, Heinaman RE, Stoler DL, Anderson GR: Uniparentalism in sporadic colorectal cancer is independent of imprint status, and coordinate for chromosome 14 and 18. Cancer Genet Cytogenet 2009, 189:77-86.

42. Van Loo P, Nordgard SH, Lingjærde OC, Russnes HG, Rye IH, Sun W, Weigman VJ, Marynen P, Zetterberg A, Naume B, Perou CM, Børresen-Dale AL, Kristensen VN: Allele-specific copy number analysis of tumors. Proc Natl Acad Sci U S A 2010, 107:16910-16915.

43. Makishima H, Maciejewski JP: Pathogenesis and consequences of uniparental disomy in cancer. Clin Cancer Res 2011, 17:3913-3923.

44. Raghavan M, Smith LL, Lillington DM, Chaplin T, Kakkas I, Molloy G, Chelala C, Cazier JB, Cavenagh JD, Fitzgibbon J, Lister TA, Young BD: Segmental uniparental disomy is a commonly acquired genetic event in relapsed acute myeloid leukemia. Blood 2008, 112:814-821.

45. Tuna $M$, Ju Z, Amos Cl, Mills GB: Soft tissue sarcoma subtypes exhibit distinct patterns of acquired uniparental disomy. BMC Med Genomics 2012, 5:60.
46. Kralovics R, Passamonti F, Buser AS, Teo SS, Tiedt R, Passweg JR, Tichelli A, Cazzola M, Skoda RC: A gain-of-function mutation of JAK2 in myeloproliferative disorders. N Engl J Med 2005, 352:1779-1790.

47. Melcher R, Hartmann E, Zopf W, Herterich S, Wilke P, Müller L, Rosler E, Kudlich T, Al-Taie O, Rosenwald A, Katzenberger T, Scholtka B, Seibold S, Rogoll D, Scheppach W, Scheurlen M, Lührs H: LOH and copy neutral LOH (cnLOH) act as alternative mechanism in sporadic colorectal cancers with chromosomal and microsatellite instability. Carcinogenesis 2011, 32:636-642.

48. Whitman SP, Archer KJ, Feng L, Baldus C, Becknell B, Carlson BD, Carroll AJ, Mrózek K, Vardiman JW, George SL, Kolitz JE, Larson RA, Bloomfield CD, Caligiuri MA: Absence of the wild-type allele predicts poor prognosis in adult de novo acute myeloid leukemia with normal cytogenetics and the internal tandem duplication of FLT3: a cancer and leukemia groupe B study. Cancer Res 2001, 61:7233-7739.

49. Emile JF, Lemoine A, Bienfait N, Terrier P, Azoulay D, Debuire B: Length analysis of polymerase chain reaction products: a sensitive and reliable technique for the detection of mutations in KIT exon 11 in gastrointestinal stromal tumors. Diagn Mol Pathol 2002, 11:107-112.

50. Peiffer DA, Le JM, Steemers FJ, Chang W, Jenniges T, Garcia F, Haden K, Li J, Shaw CA, Belmont J, Cheung SW, Shen RM, Barker DL, Gunderson KL: High-resolution genomic profiling of chromosomal aberrations using Infinium whole-genome genotyping. Genome Res 2006, 16:1136-1148.

51. Staaf J, Vallon-Christersson J, Lindgren D, Juliusson G, Rosenquist R, Höglund M, Borg A, Ringnér M: Normalization of Illumina Infinium whole-genome SNP data improves copy number estimates and allelic intensity ratios. BMC Bioinformatics 2008, 9:409.

52. Popova T, Manié E, Stoppa-Lyonnet D, Rigaill G, Barillot E, Stern MH: Genome Alteration Print (GAP): a tool to visualize and mine complex cancer genomic profiles obtained by SNP arrays. Genome Biol 2009, 10:R128.

53. Jardin F, Picquenot JM, Parmentier F, Ruminy P, Cornic M, Penther D, Bertrand P, Lanic H, Cassuto O, Humbrecht C, Lemasle E, Wautier A, Bastard C, Tilly $\mathrm{H}$ : Detection of gene copy number aberrations in mantle cell lymphoma by a single quantitative multiplex PCR assay: clinicopathological relevance and prognosis value. Br J Haematol 2009, 146:607-618.

doi:10.1186/1476-4598-13-246

Cite this article as: Lourenço et al:: Copy-neutral loss of heterozygosity and chromosome gains and losses are frequent in gastrointestinal stromal tumors. Molecular Cancer 2014 13:246.

\section{Submit your next manuscript to BioMed Central and take full advantage of:}

- Convenient online submission

- Thorough peer review

- No space constraints or color figure charges

- Immediate publication on acceptance

- Inclusion in PubMed, CAS, Scopus and Google Scholar

- Research which is freely available for redistribution 